\title{
BEARING OF THE DISTRIBUTION OF THE EXISTING FLORA OF CENTRAL AMERICA AND THE ANTILLES ON FORMER LAND CONNECTIONS *
}

BX WILLIAM TRIGLASE

(Read before the Paleontological Society December 31, 1917)

\section{CONTENTS}

Break in West Indian flora between Saint Croix and Saint Thomas ..... 649

Quercus suggests lack of land connection with North America......... 650

Nolineæ and Yucceæ indicate absence of continental land connection..... 651

Phoradendron and Furcroa suggest land connection with North and South

America .......................................652

Agave indicates relationship to a successively fragmented Antillean bridge

or spur extending southeastward from Yucatan...............6653

References......................................... 656

\section{Break in West Indian Flora between Saint Croix and Saint Thomas}

Apart from weeds of various origin and occurrence, the West Indian flora is an intricate blending of plants identical with or closely related to those of South America on the one hand and of North America on the other hand, with a relatively small proportion of true endemism of types. The chain of islands has been held for a "province" of the Tropical American floral region, correlated with the tropical Mexican province of North America and the subequatorial Andine and cisequatorial Savanna provinces of South America and contiguous Central A'merica.

The flora of Trinidad and other islands close to the South American coast is essentially a South American flora except for obvious introductions. The flora of the Bahamas may be said to have contributed characteristic elements to subtropical Florida, rather than to be a temperate North 'American flora, and it appears to be largely of Cuban derivation.

A number of years since, Baron Eggers ${ }^{1}$ showed that a considerable

* Manuscript received by the Secretary of the Society August 22, 1918.

For references, see page 656.

XLVIII-Bdut. Gror. Soc. AM., Vot. 29, 1917 
percentage (25) of the species of higher plants, as he understood them, of Saint Thomas and the adjacent Cretaceous Virgin Islands are not found in the Tertiary island Saint Croix, only some 30 miles away, and that only about 11 per cent of the species of Saint Croix occur also in Saint Thomas. As a general fact, it may be stated that those which stop in Saint Croix are endemic or derived from or represented by species of the Lesser Antilles, and of South American affinity or origin, and that those which stop in Saint Thomas, if not endemic, are of North American origin or affinity, with representatives in the Greater Antilles. Here North America does not mean or include, so far as cases are significant, the subtropical or even warm part of the United States, but it is to be understood as referring to the Mexican and Yucatecan floral zones.

It has been my privilege to become so familiar with the world representation of a few groups of plants that I may venture to speak of their geographic distribution with some confidence. What I know of them in this respect may be stated as follows:

\section{Quercus suggests lack of Land Connection with North America}

The oaks (Quercus) $)^{2}$ constitute an ancient genus, dating from the Cretaceous, scarcely changed since the Pleistocene, and apparently going well into the Pliocene essentially in their present specific forms. The genus is world-wide in its distribution in the Northern Hemisphere now. In America it is essentially North American. Only a few oaks now occur in South America - in the Andes of Colombia. These appear to me closely related to certain Costa Rican species, and thus far support the recognition of a subequatorial Andine province comparable with the cisequatorial and Central American provinces with which the West Indies are correlated in their flora. If their remains have been identified correctly, a few oaks occurred in Pliocene time in what is now arid equatorial Brazil. I have not seen specimens or illustrations of these, but should have diffculty in comparing them, as described, with existing species or with other Pliocene species of the genus.

Only one oak, scarcely differentiable from the live-oak of our Gulf States and its equivalent of the Mexican and Central American coastwise region, occurs in western Cuba. This can hardly be regarded otherwise than as an introduction from the north. The live-oaks of this type appear to represent a rather early stock among modern oaks. In the absence of paleontological evidence, it may be unsafe to attempt to say when the live-oak entered Cuba, but evidence is more necessary for the support of a hypothesis that this was in Tertiary times than for my personal view 
that it was later than the Pleistocene. Some of Catesby's oak localities have been misunderstood because of the inclusion of both continental and insular species in his illustrations; but it may be said with confidence that Quercus is unrepresented in the West Indian flora except by this single Cuban form. So far as fossil and existing oaks are known, they offer no facts pointing to a connection of the West Indies with North America in recent time. The absence of such facts may be taken as indicating that no such connection has existed.

\section{Noline and Yugcee indicate Absence of continental Land CONNECTION.}

Among the xerophytic lily-like plants I may claim sufficient familiarity with the liliaceous groups Nolineæ and Yucceæ and the Amaryllidaceous group Agavex to discuss their bearing on this question. Unlike the oaks, these are all exclusively American; and they appear to be of late Tertiary origin, though very little is known of them except as more recent plants.

The Nolinex ${ }^{-3}$ are not known to occur away from continental North America. They range from southern Colorado southwestward through Baja California and southeastward over the tableland, one of their four genera (Beaucarnea) dropping into the tierra caliente of Vera Cruz, Yucatan, and Chiapas in Mexico and the lower mountains of Guatemala. An eastern extension of another (Nolina) is known for South Carolina, Georgia, and Florida through evident derivatives of its Texan representatives, though it is absent from the intervening Gulf States. This group of the tableland, therefore, throws no light on the question, unless, negatively, the absence of its representatives from the West Indies indicates that Cuba has been connected with neither Yucatan nor Florida since the appearance of Beaucarnea in the former and of Nolina in the latter.

The Yuccex, also absent from South America, appear to be more distinctly boreal plants than the Nolineæ are. They range southward from the great bend of the Missouri River to the Atlantic and Pacific coasts, and, over the tableland, to Puebla and Jalisco. In the West Indies only one representative of this group is known, the common Spanish dagger of our Gulf States. This is fairly wide-spread through the islands, but perhaps never free from question as to spontaneity, because it is planted everywhere. ${ }^{4}$ In its genus, this species (Yucca aloifolia) is distinct in lacking a papery core to its fleshy fruit and in having acquired or retained a power of self-pollination which its congeners do not possess.

If these differences are significant, and if the Spanish dagger is native to the islands, it may be that this species acquired its distinctive charac- 
ters either in the Antilles or in the Gulf region of our Atlantic States or of Mexico, and passed from the one into the other. Since this is the only yucca with pulpy fruit in our Atlantic region, while baccate species range through Mexico as far as the genus reaches, the probability is that its prototype originated on the mainland to the south, and that in its present form it recrossed into its now rather limited areas to the north and west.

Neither of these suppositions need be regarded as indicating a land connection between the West Indies and North or Central America, for a plant with edible fruit may have passed easily greater barriers than those separating the West Indies from North America. In any event, the Yuccex offer no other indication of such a land connection, and they give no suggestion of a connection between the West Indies and South America.

\section{Phoradendron and Furcraya suggest Land Connection with NorTh AND SOJTH AMERICA}

The distinctively American mistletoe genus Phoradendron possesses a vastly greater American range than either of the groups so far considered. Species are found from ocean to ocean, and from the extreme northwestern limits of the United States to the mouth of the river La Plata, in South America. Unlike the other groups, this genus is evidently as much at home in the West Indies as it is on the continent. While the others are preponderatingly, if not exclusively, North American, this genus is almost equally well represented north and south of the Isthmus; but something like one-third as many species occur in the West Indies as on either continent. It may be, and I think is, older than either genus of Nolineæ or of Yucceæ and younger than Quercus, but no very dependable or direct evidence as to this exists.

In my study of Phoradendron, ${ }^{5}$ I became convinced that two very distinct groups-subgenera, if you like-make up the genus. One of these (the Boreales) ircludes 23 per cent of the known species; the other 77 per cent' belong to the other group (Aequatoriales). The significance of the names used for these groups lies in the fact that the first centers in Mexico and the United States, only 2 of its 66 species reaching Central America and none being found in either the West Indies or South America. 'While' hone of the Aequatoriales occurs in the United States, over half of them are South American. Of this group more occur in the West Indies than in either Mexico or Central America, though the group is well represented in both of these regions.

Unlike the oaks, these mistletoes have not passed at all from Florida 
into the West Indies, nor have they passed from the islands into the United States. A few very polymorphous species or scarcely segregable groups of species, like "P. latifolium" and "P. rubrum," are common to Brazil, Mexico, and the West Indies; except for these, the insular species are different from those of North America, and both differ from those of South America.

Have the insular species come from the northern or the southern mainland, or both, or have they passed to the tropical mainland in either or both directions and spread over it? As with Yucca aloifolia, it is not necessary to assume a land connection for the dissemination of these mistletoes. Even more than the baccate yuccas, they appear able to pass ordinary barriers, for their seeds not only are contained in edible fruits, but they are 80 viseidly adhesive as to be likely to be transported to considerable distances by birds which feed on the berries. As a matter of fact, the several species do not range over large regions, except for the few cases noted; but these and, in general, groups of intimately related species, occur in such a way as to lead one to believe that they may have passed into the Greater Antilles from the west or into the Lesser. Antilles from South America. The greater part of the Antillean species appear to me to possess South American affinities.

Agave indidates Relationship to a sUCCEgSively FRAGMENTED ANTillean Bridge or SPUR extendiNg sodtheastward. FROM YUCATAN

I have deferred until the end a discussion of the Agavere. Its two genera, apparently, are relatively modern. One (Furcroa) appears to center in South America, though it ranges from temperate Brazil to the Mexican tableland; the other (Agave) centers in Mexico, but ranges from Arizona to the Isthmus, extending across the continent in Mexico, and in some equivocal forms it occurs in tropical Florida and in Venezuela and Colombia.

Both genera are found throughout the West Indies: Furcroea in few and rather similar species; Agave in many species of several very distinct types. Furcraea appears to have entered the islands chiefly from South America. Agave is absent from South America except for a few species confined to the extreme northern region, the Colombian part of which show Costa Rican affinities. This genus appears to have penetrated the West Indies from the Mexican or Central American side.

Furcræas and agaves frequently are bulbiferous. Their bulbils are very tenacious of life; there is no telling, therefore, how far a species may 
be carried by water. Their seeds are fairly resistant, thin, and easily blown about by the wind; but there is no reason to think that this insures dissemination to any great distance. Even on the mainland, as in the classic region of Tehuacan, the species are often narrowly limited geographically. In the West Indies this restriction. is accentuated, no doubt as a result of water barriers.

The few Antillean species. of Furcrca are suggestive. One of them (F. cubensis) which occurs in Cuba and Haiti is very closely related to the Yucatecan cahum $(F$. cahum $) .{ }^{6}$ The commonest and most widespread ( $F$. tuberosa), which is found throughout the chain, is a close relative of the Brazilian species, which has been grown so long in Mauritius as to have acquired the name Mauritius hemp ( $F$. gigantea). A third species (F. macrophylla), which seems to be indigenous to the $\mathrm{Ba}$ hamas, is very like a form of northern South America. So far as these facts are indicative, they suggest immigration from both south and west; the former apparently earlier, if extent of distribution bears any relation to time.

Agave, which is represented in the West Indies by about 50 indigenous and endemic species, ${ }^{7}$ presents these in 6 distinct types: the Antillanæ, of a dozen species, are confined to the Greater Antilles; the Bahamanæ, closely allied to the preceding, and with half as many species, are exclusively Bahamian; the Caribæx, with 15 species, are confined to the Caribbees, or Lesser Antilles. These plants are all large, of the "century plant" or "maguey" type. The southernmost islands also possess a reduced edition of this type, the Viviparæ, with five species, of which one is peculiar to Trinidad and the adjacent coastwise islands, and a sixth species of the group occurs in the coast region of Venezuela. In the northern islands, also, a smaller type occurs, represented on the Greater Antilles by five species (Antillares) and in the outlying Bahamas by two very xerophytic species (Inaguenses). The Antillanæ, Bahamanæ, Antillares, and Inaguenses of the north are clearly differentiated from the equivalent Caribææ and Viviparæ of the south.

There is no evident reason why a species of either group should not range through the entire chain of islands, like the wide-spread species or group of scarcely segregable species of Furcroea ( $F$. tuberosa), but they do not do so. The Agave of Saint Thomas (A. missionum) is one of the Antillanæ; the Agave of Saint Croix, 30 miles or so away (A. Eggersiana), is one of the Caribæx. Less striking, but even more suggestive, are the facts that the species of either group are severally localized on a single island or on contiguous islands, and that species of any group 
differ in proportion to the depth of the water barriers that separate their islands and not merely in relation to the width of these barriers.

Unless Agave is assumed to have originated in the West Indies, and the problem of distribution and its present bearing would remain unchanged if this scarcely plausible assumption were made, the genus must have entered the islands from the mainland. The possibility that it entered in two directions, through northern South America and also Mexico or Central America, is not excluded. In the former case the parent stock from the south would have given rise to the Caribææ and Viviparæ, and that from the north to the Antillanæ and Antillares, with their respective offshoots, the Bahamanæ and Inaguenses. The probability, however, is that it entered from the Central American region, and that its greater groups were differentiated at a relatively early date.

Either supposition calls for belief in an essentially continuous, though not necessarily direct, land connection (perhaps broken at the present Anegada Passage) between the islands and the continents, as well as between the several islands; for as they exist today the agaves of even adjacent islands do not pass back and forth.

From what I know of the representatives of this genus in the West Indies, I am compelled to believe that they were derived from the mainland at some late Tertiary or early Quaternary time when islands and continents were continuous; that then or subsequently they have spread through the chain over continuous land; that this continuity was broken by subsidence or fault when the very deep Anegada Passage was formed; and that later subsidences have caused in succession the deeper and lesser water gaps by which the Antilles are divided into groups successively more and less distinct in their agave flora.

These conclusions are in accord with some of the less sweeping indications afforded by the other groups that I have analyzed in detail, and with the general interblending of northern and southern elements in the Antillean flora; and they are not necessarily in conflict with the negative suggestion of a lack of land connection afforded by Quercus and the Nolinex. They harmonize also with the fact indicated by Eggers, that the greatest break between these elements occurs where the deepest and presumably the oldest break in an Antillean bridge occurs, at the place where the Anegada Passage separates the islands Saint Thomas and Saint Croix, now under the flag of the United States. 


\section{REFERENCES}

${ }^{1}$ Bulletin of the U. S. National Museum, volume 13, 1879, page 13.

${ }^{2}$ Proceedings of the National Academy of Sciences, volume 2, 1916, page 626.

${ }^{3}$ Proceedings of the American Philosophical Society, volume 50, 1911, page 406.

- Report of the Missouri Botanical Garden, volume 13, 1902, page 89.

'Proceedings of the National Academy of Sciences, volume 1, 1915, page 30. W. Trelease: The genus Phoradendron, 1916, page 16.

'Annales du Jardin Botanique, Buitenzorg, 2 ser., suppl., volume 3, 1910, page 908.

${ }^{2}$ Memoirs of the National Academy of Sciences, volume 11, 1913, page 10. 